Aleksey G. Paul

\title{
BASIC QUESTIONS OF RUSSIAN BUDGET LAW REFORMS
}

The end of $20^{\text {th }}$ and the beginning of $21^{\text {st }}$ century was a period of significant reforms in Russian budget law.

Prerequisites for the Budget law reforms were transition to market economy and changes in public finance.

At the beginning of 1990s there was old uncoordinated budget legislation. Problems were complicated by economic instability in Russia which affected budget procedures. At the same time the imperfection of budget procedures led to the crisis of nonpayment and other negative consequences in economy. Thus a necessity arose to create new up-to-date budget laws.

The basis of the new budget legislation is the Constitution of the Russian Federation. It established fundamental norms for the budget law, which was followed by the process of budget law reforms.

Specialists in the Russian Ministry of Finance distinguish three stages in the budget reform ${ }^{1}$.

At the first stage it was necessary to normalize budget procedures in Russia $^{2}$, to set up the principles of budget legislation and to coordinate different budget laws. The budget legislation of that period consisted of some laws which regulated separate parts of budget relations ${ }^{3}$. That legislation was passed before the

Т. Нестеренко Этапы бюджетной реформы // “Финансы”, 2008, № 2, С. 3.

2 М. Блинов Комментарий к Бюджетному кодексу Российской Федерации // “Право и экономика”, 1998, № 12.

3 Закон РСФСР от 10.10.1991 № 1734-1 “Об основах бюджетного устройства и бюджетного процесса в РСФСР” // Ведомости СНД и ВС РСФСР, 1991, № 46, Ст. 1543; Закон РФ от 15.04.1993 № 4807-1 “Об основах бюджетных прав и прав по формированию и использованию внебюджетных фондов представительных и исполнительных органов государственной власти республик в составе Российской Федерации, автономной области, автономных округов, краев, областей, городов Москва и Санкт - Петербург, органов местного самоуправления" // Ведомости СНД и ВС РФ, 1993, № 18, Ст. 635 и Закон РФ от 15.07.1992 № 33031 "О субвенциях республикам в составе Российской Федерации, краям, областям, автономной области, автономным округам, городам Москва и Санкт-Петербург” // Ведомости СНД РФ и ВС РФ, 1992, № 34, Ст. 1972. 
Russian Constitution and collided with it, despite the fact that the laws there were special annual laws for the regulation of the budget law adoption.

At that time there were no norms for the regulation of budget execution, budgetary control or Treasury execution of budgets. Inter-budget relations were indigested.

The Russian President in the messages to Parliament in 1997 and in 1998 pointed out that the essential element to solve the problems was an adoption of the Budget Code ${ }^{4}$.

The Russian Budget Code was adopted in 1998 and came into effect in 2000.

The Budget Code set up common principles of budget legislation, budget system functioning, legal status of budget relation subjects, as well as established basics for the budget process and inter-budget relations, causes and kinds of responsibility for budget offences.

So, the Budget Code created a comprehensive system of budget regulations. It included the rules which earlier had been contained in different laws. Moreover, as some authors claim, the Budget Code solved the problem of budget legislation perfection ${ }^{5}$.

However, the realization of the Budget Code showed that a great number of its rules did not work properly. So the authorities had to introduce amendments thereto.

The second stage of the budget reform was concerned with changing in inter-budget relations. The beginning of the reform revealed several significant problems concerning budget competence of different levels of authority. There was no precise delimitation therein. The Russian Federation adopted a great deal of laws which created expense obligations for regions and municipalities. At the same time regions and municipalities did not have enough revenues to execute them. It led to a great number of suits against the Treasury.

In 2001 Russian Government worked out the Program of development of budget federalism ${ }^{6}$. Its main purpose was to form and develop budget arrangements

4 Послание Президента РФ Федеральному Собранию от 6 марта 1997 г. "Порядок во власти - порядок в стране" (О положении в стране и основных направлениях политики Российской Федерации) // “Российская газета”, 1997, 7 марта (№ 47); Послание Президента РФ Федеральному Собранию от 17 февраля 1998 г. "Общими силами - к подъему России (О положении в стране и основных направлениях политики Российской Федерации)" // “Российская газета”, 1998, 24 февраля (№ 36).

5 Т. Конюхова Важный шаг на пути совершенствования бюджетных правоотношений. К принятию Бюджетного кодекса Российской Федерации // “Журнал российского права”, 1998, № 10-11.

6 Постановление Правительства РФ от 15.08.2001 № 584 "О Программе развития бюджетного федерализма в Российской Федерации на период до 2005 года // Собрание законодательства РФ, 2001, № 34, Ст. 3503. 
so that every authority level could lead its own tax-budget policy according to the established differentiation of competence and responsibility.

The implementation of the Program resulted in the change of the Budget Code. Amendments were adopted in $2004^{7}$. The amendments concerned some aspects of inter-budget relations and solved the problems through the following measures:

1) introduction of clarity into the delimitation of authority levels' competence;

2) specification of budget arrangements and principles of the budget system;

3) delimitation of tax revenues between different budget levels;

4) delimitation of expense obligations between different budget levels;

5) regulation of inter-budget transfers;

6) regulation of budget power implementation for regional and local levels concerning conditions of temporary finance administration;

7) clarifying the order of budget execution.

That system of amendments established a legal basis for new inter-budget relations.

The third stage of the reform was devoted to the increasing in the effectiveness of budget expenses. It started with the adoption of the Conception of budget process reforming in 2004-2006 ${ }^{8}$.

The main purpose of the Conception was the creation of conditions and prerequisites for effective management of public finance according to the state policy priorities.

The new approaches were expected to increase attention to the tax-budget policy, medium and long-term budget planning with the aim of financial stability and effectiveness of the state expenses as well as the increase in the responsibility for the results of using tax payers` money.

This stage of the budget reform included the following orientations:

1) One of the main elements of the budget reform was a transition to a mediumterm (long-term) budgeting. According to it, a budget cycle starts with the consideration of the main parameters of a medium-term finance plan for the corresponding year, which had been approved of in the previous budget cycle,

7 Федеральный закон от 20.08.2004 № 120-Ф3 “О внесении изменений в Бюджетный кодекс Российской Федерации в части регулирования межбюджетных отношений” // Собрание законодательства РФ, 2004, № 34, Ст. 3535.

8 Утверждена Постановлением Правительства РФ от 22.05.2004 № 249 “О мерах по повышению результативности бюджетных расходов” // Собрание законодательства РФ, 2004, № 22, Ст. 2180. 
the analysis of changeable external factors and conditions, the substantiation of changes in basic budget characteristics for the planned year, as well as the correction or development of budget projects for the following years of the planned period 9 .

In 2007 the amendments were made to the Budget Code of the Russian Federation due to which the budget is drawn not for a year but for three years, or, to be more exact, for the next financial year and the predicted period. Accordingly, on 24 June, 2007 the Federal law "On the Federal Budget for 2008 and 2009-2010 planned period" was adopted.

As the author of the changes in the Budget Code of the Russian Federation noted, the method of "a slipping three-year-period," well-known in international practice, constituted the basics of budgeting. In accordance with this method the formerly approved projects for the second and third years of a 3-year-period become the foundation of the next budget with an annual addition of new third-year projects ${ }^{10}$.

"A slipping three-year-period" guarantees on the one side stability and predictability of budget projects and, on the other side, an ability to react to a changing situation, restructuring of liabilities and implementation of new priorities in the budget policy.

The medium-term principle (usually 3 years) is in the basis of the budget planning of the most developed countries, such as Great Britain, Canada, the Netherlands, Sweden, Denmark, Finland, Norway, France, Australia and New Zealand ${ }^{11}$.

2) The main direction in the Russian budget law reform in the last years was a transition to the primarily program-objective methodology of budget planning.

Previously, the Russian budget was mainly formed by indexing of the used expenses. There were no substantiations to the expected results of the budget expenses and budget management was more often turned into the control of factual and planned results.

Subsequently, it was decided to introduce the "result management" conception under which the budget is formed on the basis of state policy planned results. The budget allocations are directly connected with the functions (services, activities) and

9 Концепция реформирования бюджетного процесса в Российской Федерации в 2004 - 2006 годах. Утверждена Постановлением Правительства РФ от 22.05.2004 № 249 “О мерах по повышению результативности бюджетных расходов" // Собрание законодательства РФ, 2004, № 22, Ст. 2180.

10 Пояснительная записка к проекту Федерального закона "О внесении изменений в бюджетный кодекс РФ в части регулирования бюджетного процесса и признании утратившими силу отдельных законодательных актов Российской Федерации" // www.consultant.ru.

11 С. Тюнина, М. Шамьюнов Профессиональный взгляд на новый Бюджетный кодекс // “Финансы”, 2007, № 8, C. 13 . 
when planned much attention is paid to the final results within the framework of the budget programs.

According to the authors of the reforms a widely spread model of "budgeting oriented towards results within the framework of the middle-termed finance planning" should become the nucleus of the new budget process organization. Its essence lies in the allocation of the resources in accordance with the real results (supplied services) and taking into consideration medium-terms priorities of the social-economic policy and within the long-term forecast budget resource volume ${ }^{12}$.

The established budget allocation planning adjusted for the state (local) tasks must be of great importance now as it will have to describe the volume, enumeration, quality and conditions for providing state (local) services for both individuals as well as organizations.

Besides, various single purpose programs must play an important part in resultoriented budgeting.

The new edition of the Budget Code of the Russian Federation allows for longterm single purpose programs, departmental special purpose programs as well as the federal targeted investment program. It is exactly these programs where the predicted results of budget expenses must be clearly defined.

3) The Russian Federation Budget Code rules concerning budget expenses splitting in accordance with their economic allowance for current and capital have been considered out-of-date.

These changes correspond to universally accepted principles of public finance management. The idea of budget splitting into current and capital spending cannot be counted in the range of modern methods of budget planning and state (public) management.

The separate current and capital budget formation is still practiced by a number of developing countries, sometimes because of a large-scaled support provided by donors and international creditors.

In fact, by now budget splitting has been unanimously recognized out-ofdate, methodologically faulty and unsuitable in terms of advanced public finance management.

International practice testifies that spending results are improving and the level of control and stability is increasing when current and capital expenses are managed on the basis of consolidation within the framework of long-term planning.

12 Концепция реформирования бюджетного процесса в Российской Федерации в 2004 - 2006 годах. Утверждена Постановлением Правительства РФ от 22.05.2004 № 249 "О мерах по повышению результативности бюджетных расходов" // Собрание законодательства РФ, 2004, № 22, Ст. 2180. 
The integration of current and capital spending management is a key factor in providing general stability for the budget, in enhancing the effectiveness of budget programs and investment projects with due regard of their overall costs and results achieved $^{13}$.

As the analysis of investment cost planning in some countries demonstrates, current and capital expenses are planned, observed and ratified within the framework of a single budget. This is true about such developed countries as Great Britain, the USA, the Netherlands, Germany, France and others ${ }^{14}$.

The program-based and objective-oriented methods of planning are successfully carried out if current and capital expenses are viewed as a whole. Objective-oriented budgeting presupposes the choice of the most effective ways of using the budget to achieve the objectives. Thus, if some expenses formed specifically are distinguished, this choice is limited.

4) The effective budget reserves management can be crucial in providing the stability of public finance.

The majority of the countries where oil is extracted (such as Azerbaijan, Kazakhstan, Kuwait, Norway, Venezuela) use special management regime to control state profits from the oil sector. Such management regimes are also used in some federal states (Alaska, for example) ${ }^{15}$.

Russia, as many other countries profiting from the natural resource export, has considered it indispensable to form the Stabilization Fund, which accumulates the returns from oil and gas exports, in order to avoid fluctuation in these restricted incomes that can undermine the financial stability of the country.

Oil and gas incomes were first accumulated into the Financial Reserve which later was transformed into the Stabilization Fund. Nowadays the Stabilization Fund is reorganized into two funds: the Reserve Fund and the National Well-being Fund.

We should point out that the above-mentioned funds were formed and are now being formed as a part of the Federal Budget rather than independent funds.

The Reserve Fund must provide for the spending of the Federal Budget in case of a significant decrease in oil prices in the medium-term perspective and the rise of deficiency connected therewith. The National Well-being Fund must accumulate the oil and gas incomes which occur as a result of a surplus of incoming returns from oil

\footnotetext{
13 Принципы эффективного и ответственного управления общественными финансами // "Государственная власть и местное самоуправление", 2006, № 12.

14 С. Тюнина, М. Шамьюнов Профессиональный взгляд на новый Бюджетный кодекс // “Финансы”, 2007, № 8, C. 13.

15 И. Гетьман-Павлова Управление Стабилизационным фондом РФ: проблемы правового регулирования // “Банковское право", 2007, № 4.
} 
and gas industries as well as deductions made into the Reserve Fund, and the funds which are used to finance the expenses of the Federal Budget. The main purpose of the National Well-being Fund is to retain part of the incomes from irreplaceable natural resources in order to use them when resources are exhausted. These funds must work to improve the well-being of both present and future generations.

5) One of the directions which the budget reform in Russia has taken is the adjustment of the budget classification to international standards.

The changes in the Budget Code of the Russian Federation of 2007 enabled to meet the requirements of international standards and to implement the integrated plan of budget classification calculated on accrual basis.

The aforesaid changes were connected with implementation of programobjective methods in budget planning.

It was decided to renounce the practice of ratifying the budget classification by a special federal law. Instead the Budget Code of Russian Federation only sets the main codes of budget classification obligatory for all levels of the state budget system This approach is applied by most countries of the international community. More detailed structure of the classification is determined by local authorities when adopting a budget statute. Such an approach gives more independence and responsibility to local authorities while preparing a budget project within the frame of uniform principles of budget classification.

Thus, the Russian budget law of the last few years has experienced several stages of reforms. It transformed from a set of uncoordinated incomplete law into a well-ordered system. Some solutions were adopted from international experience. However, some changes have not been completely implemented yet. 


\section{Streszczenie}

Koniec XX i początek XXI w. był okresem znaczących reform rosyjskiego prawa budżetowego. Został on podzielony na trzy etapy.

W pierwszym - uchwalono Rosyjski Kodeks Budżetowy (1998), który zaczął obowiązywać od roku 2000. Dzięki niemu usprawniono procedurę budżetową, ustanowiono zasady legislacji budżetowej oraz ujednolicono regulacje prawne $\mathrm{z}$ tego zakresu.

W drugim okresie reforma została skoncentrowana na poprawie relacji międzybudżetowych. W 2001 r. rosyjski rząd opracował program rozwoju budżetu federalnego.

Etap trzeci dotyczył poprawy efektywności wydatków budżetowych. Począwszy do 2007 r. budżet rosyjski projektowany jest na następny rok oraz na dwa kolejno następujące lata budżetowe. Rozpoczęto również stosowanie programowo-zadaniowej metodologii planowania budżetowego. 